\title{
The future role of mobile learning and smartphones applications in the Iraqi private universities
}

\author{
Mohammad Abdulrahman Al-Mashhadani ${ }^{1^{*}}$ (D) and Marwah Firas Al-Rawe ${ }^{2}$
}

\author{
* Correspondence: mar.7474@mail.ru \\ 'Department of Computer \\ Techniques Engineering, Al-Maarif \\ University College, Ramadi, Iraq \\ Full list of author information is \\ available at the end of the article
}

\begin{abstract}
The higher education sector has witnessed a drastic change due to new advanced technologies including computers and smartphones. As a result, higher education will need to establish a solid foundation aided by information communication technologies (ICT) where mobile applications can extend learning opportunities for students and graduates so they meet the requirements of the fast-changing jobs market. Many studies conducted in various contexts have revealed the drastic change of using mobile applications (henceforth apps) and advanced communication which help students develop their skills by means of using the digital environment. The study aims at identifying the general impression of Iraqi private universities students about the future role of ICT and the mobile learning in higher education. Al-Maarif University College is selected as a case study to measure the extent of students' reliance on the use of modern smartphones applications in research, study, and skills development in the field of specialization. The study also sheds light upon specifying the important variables and methods for enhancing the role of the mobile learning as a part of the electronic education for the private education sector in Iraq.

Keywords: Information communication technology (ICT), Private higher education, Mobile applications, Mobile learning, E-learning
\end{abstract}

\section{Introduction}

Many drastic changes have taken place for the higher education sector because of the new developments in information communication technologies using computers, smartphones and their apps. International organizations such as United Nations have recognized information communication technologies as a useful tool at different learning sectors. Accordingly, many developed countries invest information communication technologies in the infrastructure. Focusing on technology-based learning methods is to cope with the various learning methods among young people and even third world countries are making efforts to benefit from technological expansion in the field of computers and smartphones (Olasoji et al. 2014).

Smartphones and iPads are popular amongst college students due to their being easily carried, wireless, containing many apps making it easy for the student to do multiple tasks at one stand, and connecting while roaming. All of these have helped increase the popularity of mobile devices due to their ability to handle multiple tasks. Furthermore,

(C) The Author(s). 2018 Open Access This article is distributed under the terms of the Creative Commons Attribution 4.0 International License (http://creativecommons.org/licenses/by/4.0/), which permits unrestricted use, distribution, and reproduction in any medium, provided you give appropriate credit to the original author(s) and the source, provide a link to the Creative Commons license, and indicate if changes were made. 
commercial competitive industry has compelled manufacturers to present new creative features of competitive traits (Ismail et al. 2013).

Thus, it has been noticed that those devices have a great impact upon the nature of higher education, the advanced learning methods, and the future role of those devices in developing and specifying alumni skills.

Because smartphones extend the learning environment the addition of learning environment by using smartphones and its apps represent a highly developed trend in higher education sector and e-learning, because of the easily transmitted teaching experiences via smartphones, as well as the use of educational programs and the transfer of information outside the routine use of information communication technologies in higher education institutions (Ozuorcun and Tabak, 2012).

At the Iraqi educational institutions, e-learning is considered as a new mode of the advanced academic learning. The pre-stage of the present study has shown that a few numbers of the Iraqi Official Universities have adopted computer-based teaching strategies for their students. This is attributed partially to the high cost investment for this sector. Launching from this point, special attention is paid for the private higher education in Iraq, the adoption of the e-learning strategy, and the increase in the mobile educational apps using mobile for those universities are considered a good arena for those programs for the following reasons:

1- The feasibility of those devices and their apps for the educational process for private and official universities students.

2- The future look to upgrade the private universities outcomes to cope with the requirements of the future jobs market.

3- The financial possibilities available for the private education sector in Iraq and the possible communication and negotiation with the private employment sector.

\section{The research questions}

The following questions sum up the research contributions:

1- To what extent private universities students depend on mobile apps?

2- Can the students visualize the role and the impact of information communication technology for their study?

3- In what situations do students prefer using mobile apps for the learning process?

4- Is there a need to add the training on mobile apps-usage to the programs of curricula?

\section{Aim and objectives}

The study aim at discovering the general attitude and vision of private universities students towards the role of mobile apps for learning, training, and speciality-skill development and the future role of the mobile apps on private higher education. Al-Maarif University College at Al-Anbar governorate is the case study. The specified objectives were:

1- Estimating the scope of using information communication technology among private Universities students. 
2- Identifying the students' anticipation on the future role of smartphone apps.

3- Recognizing how far it is needed for training students on smartphones apps to enhance their speciality and moulding it in the curricula.

4- Recognizing how far students are able to handle with the information communication technology.

5- Specifying websites, social media, and e-forum role for the learning process and how the students handle with these sites by using smartphones.

\section{Hypotheses}

Depending on the research questions, the study hypotheses are as the following:

1- There is a significant impact between smartphone apps usage abilities and developing those skills to develop quality assurance regarding educational outputs and the compatibility of educational outputs for the electronic labour market.

2- There is a direct correlation between smartphones apps professional usage for the learning process, training and skill- development for the private Universities alumni.

3- The future look of students about smartphones apps for the learning process is associated with the lack of training on these apps.

\section{E-learning and M-Learning}

E-learning is still developing slowly in third world countries. The concept of e-learning in most departments in the Iraqi universities focuses on learning computer components and some Microsoft office applications. This deprives students and learners from reaching out the learning materials and methods of identifying the new educational products through computer and mobile phones apps which have fast growing tendencies in the e-markets.

The rapid growth of mobile apps has helped make mobile devices a new tool for learning because, on the one hand, those devices are easily carried and on the other they increasingly support and shorten learning modes and cooperative e-learning (Aghaee and Larsson, 2013).

Mobile learning is defined as the type of learning that can be accomplished by using mini computers. Those include smartphones, iPads, and the like which are all considered modes of e-learning (Zhang, 2015a, b).

Traxler et al. specify mobile learning as all the digital and wireless technological types that are presented for the public and used by higher education learners. Other researchers deplore the concept of mobile learning as the transmission of learning between learners at the same time by using mobile phones (Traxler 2007).

Mobile learning has become a relatively new tool for the learning process of many students who found it easy to use the many options available for them such as websites, net pages concerned with learning and training, and mobile apps that facilitate and support the learning activities.

Smartphones and iPads contribute to leaning process greatly as students use the educational content they offer in such a way that let them control their content especially when there are no laptops or desktops available (Kimura, n.d.).

Published studies concerned with mobile learning appeared in 2000. Sharples discussed in Computer and Learning Journal the possibility of using new designs for 
personal mobile phones that can support teaching programs for students for different specialities and the many opportunities for them (Sharples 2000). Based on Sharples, many articles and researches have been conducted circulating around mobile learning and its relation to e-learning.

In recent years, many researchers have focused on mobile learning, its statistics, users of those teaching modes as conducted by Liu et al. (Liu et al. 2009). A study of Paul TJ James has focused on the dependency of mobile devices in doing learning and education. This dependency is not itself in all countries in which the researchers have discovered this case separately vis those researchers (James 2008).

Mobile learning is relatively new among students as its launching has not exceeded five years. Crompton et al. has tackled the mobile learning in educational fields. It has been found that the spread of mobile phone apps is very common in various university context specifically university primary studies. The study has also found that most previous studies and researches had focused on designing mobile learning systems while there is a necessity to conduct the effects of mobile learning (Crompton and Burke, 2014).

Lohr's study has presented the use of iPads for higher education sector. The study reveals that those devices enhance the learning experience but not the outcome of the educational institutions (Lohr 2011).

The current studies provide a general insight for the current trends of mobile learning for universities and educational institutions. Furthermore, those studies do not provide a detailed analysis for the private educational institutions.

\section{The role of Mobile apps for higher education}

According to the International Union of communication and the International Bank league of information communication technology report in 2016, Iraq is considered a good place for using smartphones for various fields (Mobile cellular subscriptions n.d.).

Higher education sector has been undergoing a multiple usage of mobile apps in various worldwide universities (Ten billion downloads n.d.). Some of those apps have been used as teaching tools, study guide, college apps marketing, freshmen guide, and admission and registration regulations (Mobile Learning Application 2017). Those apps aim at preparing students for college life experiences and saving time and energy for study. Teaching based apps help students write down lectures, testing their knowledge, and peers cooperation (Zhang, 2015a, b).

Mobile apps have been developed to be used on smartphones and iPads. Their earlier versions such as mobile tune games, tune editor, calculators, and calendars have been developed and increased rapidly. Companies and app developers and engineers start producing certain app categories targeting certain users including various speciality college students. But generally, those apps serve college students in different departments.

Strain explained that mobile apps marketing was mainly concerned with mobile application industry that manufacturers various platforms for certain users. Since then, higher education has dealt with mobile application industry intensively. For instance, Google has launched its educational mobile apps in 2006, while Apple has in 2008.

For years, educational mobile apps has become millions profit fund especially those concerned with college students. Besides, mobile apps in higher education sector represent a subsidiary field used for fund raising and probably designed for special aspect of the student's experience (GSMA establishment). 
Mobile apps can be considered learning aids. Medical students can find anatomy app a useful tool for learning. Also, mobile apps help in astronomical supervision and phenomena and those that mimic the lab environment for students of organic chemical departments and many others ((Suki 2013); (Fraknoi 2011); (Dekhane and Tsoi, 2012)).

Numerous studies reveal that students predict a positive impact from mobile learning. That is, students think that mobile phones help them engage with relevant material and raise their confidence as learners (Mueller et al. 2012). Moreover, those mobile phones and apps contain many categories having learning tools and traits, short, mid, and final exams notifications, learning videos issued by teaching staff, and others that achieve success for students' learning process (Sass 2015). The availability of those mobile phones, students are interested to cope with the college updates through those apps instead of desktop computer. Students believe that their colleges should support such apps. While some studies show that students spend more time using desktop computer to reach out the same information they can have in less time if they use mobile apps. This gives rise to students to use mobile apps.

As a response to this demand, universities have developed an app specified for university, college, or department. Those apps are not educational but referential to help students reach out college announcements, calendars, exams seating plans and schedules, training and developmental courses and many other activities. This increasing usage must be coped with an increase in e-training of how to use those apps and the best methods to utilize information technology and communication resources those apps provide.

\section{Data collection and analysis}

The study has been conducted at Al-Maarif University College - Anbar - Iraq. Research sample consists of some students from departments of Law, English Language, Finance and Banking, Arabic Language, and Medical Laboratory Techniques Departments. A questionnaire has been conducted for data collection. It consists of 16 questions including the dependent and stable research variables. 100 copies have been distributed among research sample and only 92 ones have been regained. This questionnaire is divided into qualitative and quantitative. The quantitative data consists of (10) closed questions while the quantitative data consists of (6) questions representing the outcomes of research variables.

\section{Quantitative data analysis (closed questions)}

The first ten questions of the questionnaire have been divided into four axes:

1- Knowing how to use mobile phones apps in the education process.

2- Using mobile phones apps and websites for learning.

3- Training and skill development using mobile phones apps.

4- E-research and e-lectures by using mobile phones apps.

Students' answers percentages for the first ten closed questions are presented in (Table 1). 
Table 1 Sample answers on the closed questions

\begin{tabular}{|c|c|c|c|c|}
\hline \multicolumn{5}{|c|}{ sample size $(n=92)$} \\
\hline No. & Item & agree & neutral & disagree \\
\hline 1. & Are you aware of the good use of computers, smartphones or iPads? & 60.68 & 36.94 & 2.17 \\
\hline 2. & $\begin{array}{l}\text { Are those devices easy and effective in providing useful information about } \\
\text { your college speciality and curricula? }\end{array}$ & 85.86 & 13.03 & 1.08 \\
\hline 3. & $\begin{array}{l}\text { Do you know websites you can reach to collect the required information } \\
\text { for your curricula? }\end{array}$ & 66.3 & 20.64 & 13.04 \\
\hline 4. & $\begin{array}{l}\text { Do you prefer search online for your study materials or going to the college } \\
\text { library? }\end{array}$ & 56.52 & 31.52 & 11.95 \\
\hline 5. & $\begin{array}{l}\text { Would you like to develop and your abilities and skills in your speciality by } \\
\text { looking for information online? }\end{array}$ & 71.72 & 22.82 & 5.43 \\
\hline 6. & Do you have a certain apps on your smartphone that help you in your study? & 56.52 & 11.95 & 31.52 \\
\hline 7. & $\begin{array}{l}\text { Are you registered on a webpage or website that handle your study and } \\
\text { speciality? }\end{array}$ & 44.56 & 10.86 & 44.56 \\
\hline 8. & $\begin{array}{l}\text { Do you prefer searching study materials in e-libraries in your spare time } \\
\text { using computer or smartphones? }\end{array}$ & 46.73 & 36.94 & 16.3 \\
\hline 9. & Do you think e-lectures will help you in your study more than printed ones? & 40.21 & 33.68 & 26.08 \\
\hline 10. & Are study courses taught available online? & 20.65 & 42.38 & 36.95 \\
\hline
\end{tabular}

Answers have been analysed according to Likert's triple scale using SPSS program as in (Table 2). The internal consistency (Cronbach's alpha factor) for the four axes was 0.805 .

After examining the relation between the research variables, it has been found that there is a positive correlation between the axis "knowing how to use of mobile apps" and the axis "training and developing those skills". This relation is manifested by Pearson correlation of (0.736) at a correlation level (0.01). This relation shows although students have not received any training, their knowledge and personal-taught skills for those apps are the motives to develop the required learning app usage. This is an indication of the importance of "knowing how to use and how to use" mobile phones and apps in developing students' skills and motivating them to gain experience throughout professional usage of those apps and this support the first hypothesis as in (Table 3).

Table 3 shows a positive correlation between study based e-research and training and developing skills in which the correlation is (0.612) at a correlation level $(0.01)$. There is an increase correlation when an increase of mobile apps training and their insertion

Table 2 Statistic answers on the closed questions

\begin{tabular}{|c|c|c|c|c|c|}
\hline \multicolumn{2}{|l|}{ Item Statistics } & \multicolumn{2}{|l|}{ Mean } & Std. Deviation & $\mathrm{N}$ \\
\hline \multicolumn{2}{|c|}{ E-research and e-lectures } & \multicolumn{2}{|l|}{2.46507} & .480506 & 92 \\
\hline \multicolumn{2}{|c|}{ Using mobile phones apps } & \multicolumn{2}{|l|}{2.40259} & .506985 & 92 \\
\hline \multicolumn{2}{|c|}{ Knowing how to use mobile phones apps. } & \multicolumn{2}{|l|}{2.09350} & .666656 & 92 \\
\hline \multirow{2}{*}{\multicolumn{2}{|c|}{ Training and skill development }} & 2.12213 & & .754887 & 92 \\
\hline & & \multicolumn{4}{|c|}{ Case Processing Summary } \\
\hline Cronbach's Alpha & $\mathrm{N}$ of Items & & & N & $\%$ \\
\hline \multirow[t]{3}{*}{.805} & 4 & Cases & Valid & 92 & 100.0 \\
\hline & & & Excluded $^{a}$ & 0 & .0 \\
\hline & & & Total & 92 & 100.0 \\
\hline
\end{tabular}


Table 3 The correlation between the four axes

\begin{tabular}{llllll}
\hline Correlations & \multicolumn{1}{l}{$\begin{array}{l}\text { Pearson } \\
\text { Correlation } \\
\text { Sig. (2-tailed) }\end{array}$} & $\begin{array}{l}\text { E-research } \\
\text { and e-lectures }\end{array}$ & $\begin{array}{l}\text { Using mobile } \\
\text { phones apps }\end{array}$ & $\begin{array}{l}\text { Knowing how } \\
\text { to use mobile } \\
\text { phones apps }\end{array}$ & $\begin{array}{l}\text { Training and } \\
\text { skill development }\end{array}$ \\
\hline E-research and e-lectures. & 92 & 1 & $.485^{* *}$ & $.499^{* *}$ & $.612^{* *}$ \\
& & & .000 & .000 & .000 \\
Using mobile phones apps & 92 & 92 & 92 & 92 & 92 \\
& & $.485^{* *}$ & 1 & $.305^{* *}$ & $.446^{* *}$ \\
Knowing how to use mobile & 92 & .000 & & .003 & .000 \\
phones apps. & 92 & 92 & 92 & 92 \\
& $.499^{* *}$ & $.305^{* *}$ & 1 & $.736^{* *}$ \\
Training and skill development & 92 & .000 & .003 & & .000 \\
& 92 & 92 & 92 & 92 \\
& $.612^{* *}$ & $.446^{* *}$ & $.736^{* *}$ & 1 \\
\hline
\end{tabular}

${ }^{* *}$ Correlation is significant at the 0.01 level (2-tailed)

as a teaching mode causes an increase in research on the Internet looking for resources and e-lectures which validates the second hypothesis.

\section{Qualitative data analysis (open questions)}

Examine the research sample answered about the time consumed on Internet for resource search and learning requirements, the percentages of those answered are as the following:

\begin{tabular}{lll}
\hline Item A & $\begin{array}{l}\text { How long can you surf the Internet every day for the purpose } \\
\text { of studying, learning and developing skills in your field? }\end{array}$ & Percentage of answers \\
\hline 1. & Less than $1 \mathrm{~h}$ & 38.04 \\
2. & $1-3 \mathrm{~h}$ & 52.17 \\
3. & More than $3 \mathrm{~h}$ & 9.78 \\
\hline
\end{tabular}

The reasons of such usage and reactions are as the following:

- Lack of training of the using speciality-related mobile apps.

- Difficulty in using pages and websites that support the learning process and related courses.

- Language problems in all learning apps are developed with a foreign language.

The future anticipation of students about the role of smartphones and their support for e-learning throughout e-lectures. Percentages have revealed that answers classification as the following:

\begin{tabular}{lllr}
\hline Item B & $\begin{array}{l}\text { Do you think computers and smartphones technology would replace } \\
\text { handbooks or regular lectures in the future? Give one reason. }\end{array}$ & Agree & Disagree \\
\hline & 47.12 & 52.87
\end{tabular}


Reasons vary between the lack of support of private universities and colleges for those programs and the poor computer and smartphones technology teaching curricula especially in the humanitarian specialities.

Answers for the open-ended section concerning computer and smartphones technology and its role in enhancing learning methods and activities, percentages have revealed:

\begin{tabular}{|c|c|c|}
\hline Item C & $\begin{array}{l}\text { Do you think computer and smartphones technology use } \\
\text { would enhance learning methods and activities? }\end{array}$ & Percentage of answers \\
\hline 1. & Agree & 79.34 \\
\hline 2. & Neutral & 13.04 \\
\hline 3. & Disagree & 7.6 \\
\hline
\end{tabular}

Concerning the section of the quality of electronic devices students' preferred use for learning and coping with scientific advances of studying, specialization, and educational requirement, percentages reveal the following:

\begin{tabular}{lll}
\hline Item D & $\begin{array}{l}\text { Which of the following devices do you prefer to use for learning } \\
\text { and cope with scientific advances in your field of speciality? }\end{array}$ & Percentage of answers \\
\hline 1. & Laptops & 29.21 \\
2. & Smartphones & 64.05 \\
3. & iPads & 6.74 \\
4. & None of the above & 0 \\
\hline
\end{tabular}

However, the responses to item (D) by the sample (92 students) that supported the use of mobile and mobile apps as an effective tool in learning and skills development were not identical in all departments as in Fig. 1. The departments of English language and Medical laboratory techniques strongly supported the use of smart phone applications in the smart learning environment. Because of the large number of mobile applications on the web-stores that support effectively the learning processes and skill development in the above departments.

The departments of Arabic language and law did not support the use of smart phone applications as their colleagues in other departments because most applications do not directly support the Arabic language and the weakness of use English language.

It has been shown that the majority of students prefer using smartphones for learning and coping with scientific advances. Students' answers concerning the open section of supporting the insertion of computer and smartphones technology training validate research hypotheses. $86.95 \%$ of students have agreed upon the insertion of speciality-related computer and smartphones technology training in curricula. This validates the third hypothesis.

The last section concerning websites and pages students prefer using for learning purposes and skill enhancement by using smartphones, its percentages are as illustrated in (Fig. 2). 


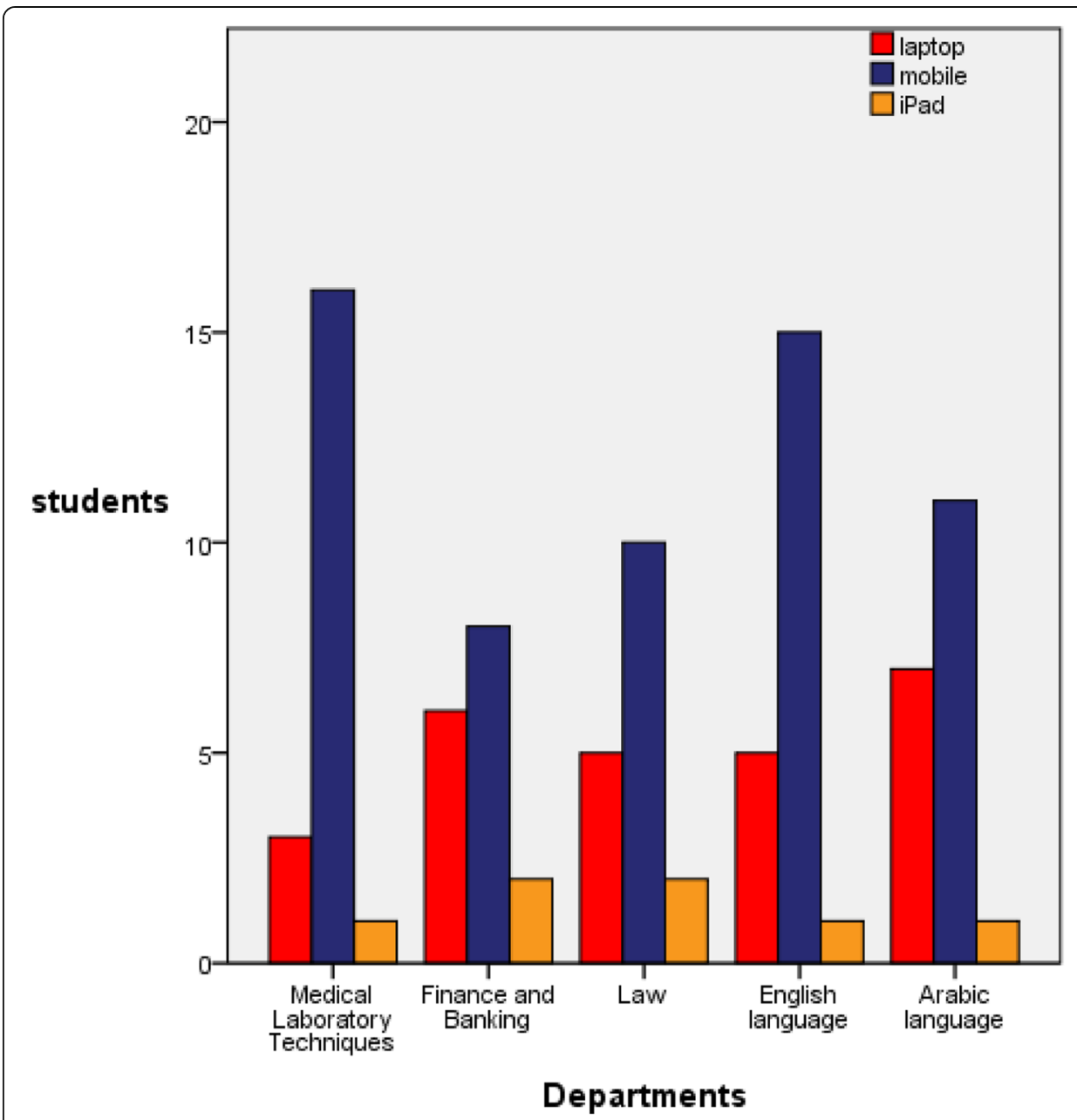

Fig. 1 The use of mobile, laptop and iPads in learning process and skill development

\section{Conclusion and suggestions}

\section{Conclusion}

Results of the present study are summarized as the following:

1- Optimal usage of computer and smartphones apps can enhance the outcomes of private universities and colleges providing well-trained and electronically qualified alumni for the requirements of working industry market.

2- Many international universities and colleges have started to update higher education sector systems by using information technology and communication and depending on it for reconstruction investment.

3- The increasing investment in information technology and communication will help increase private universities and college's scientific integrity and novelty of those establishments by their adaptation of the new various teaching programs. 


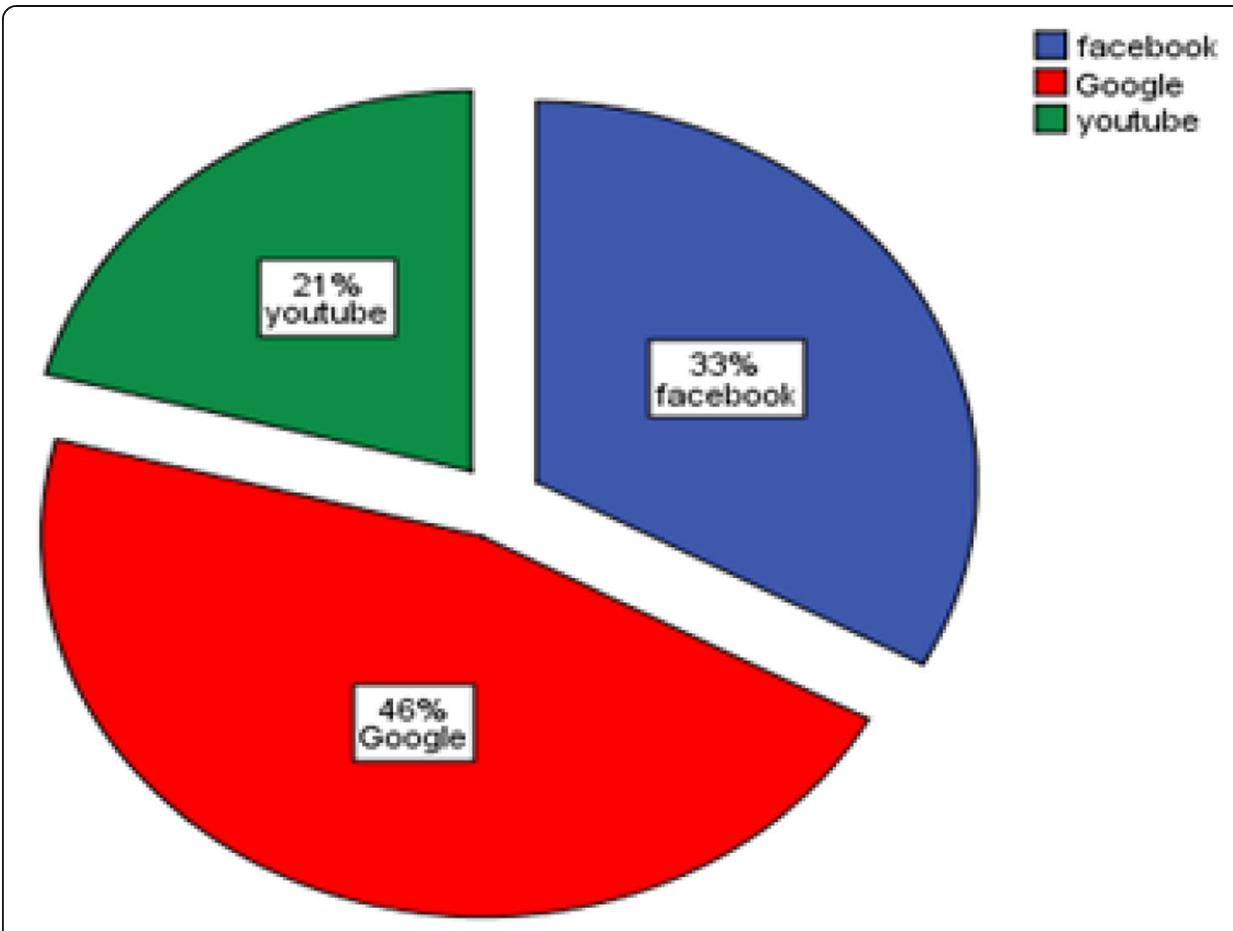

Fig. 2 Websites searching by using smartphones

\section{Suggestions}

- There is the need to highlight the role of technology for higher education sector and prepare the proper procedures to equip students with the best methods for the best usage.

- There must be as part of private college curricula a serious tendency for the insertion of information technology and communication training programs by of using on the new and requirement-based applications.

- The study presents a new hypothesis in accordance with the use of technology as a teaching tool. Thus, colleges are required to be aware of these technologies to facilitate and direct the learning process.

- The past five years have come up with a tremendous outcome in the advanced techniques and strategies of information technology by focusing on investing in the cloud auctions and super-similar devices. Furthermore, profit-change management in the higher education sector can be handled throughout this technology in which Iraqi private universities and colleges would be the raw material for this change.

\section{Funding}

No funding received.

\section{Availability of data and materials}

All data collected based on a questionnaire in Al-Maarif University College at Al-Anbar governorate in Iraq.

\section{Authors' contributions}

MAA carried out the molecular genetic studies, participated in the sequence alignment, participated in the design of the study, performed the statistical analysis and drafted the manuscript. MFA participated in the revision of English language and helped to draft the manuscript. Both authors read and approved the final manuscript.

\section{Competing interests}

The authors declare that they have no competing interests. 


\section{Publisher's Note}

Springer Nature remains neutral with regard to jurisdictional claims in published maps and institutional affiliations.

\section{Author details}

${ }^{1}$ Department of Computer Techniques Engineering, Al-Maarif University College, Ramadi, Iraq. ${ }^{2}$ Department of English language, Al-Maarif University College, Ramadi, Iraq.

\section{Received: 26 September 2018 Accepted: 22 October 2018}

\section{Published online: 06 November 2018}

\section{References}

N. Aghaee, K. Larsson, Students' perspectives on utility of Mobile applications in higher education. Communications in Computer and Information Science Trends in Mobile Web. Inf. Syst., 44-56 (2013). https://doi.org/10.1007/978-3-319-03737-0_6

H. Crompton, D. Burke, Review of trends in Mobile learning studies in mathematics: A meta-analysis. Mobile as a Mainstream - Towards Future Challenges in Mobile Learning Communications in Computer and Information. Science, 304-314 (2014). https://doi.org/10.1007/978-3-319-13416-1_29

S. Dekhane, M.Y. Tsoi, Designing a Mobile application for conceptual understanding. International Journal of Mobile and Blended Learning 4(3), 34-52 (2012). https://doi.org/10.4018/jmbl.2012070103

A. Fraknoi, Astronomy apps for Mobile devices. A First Catalog. Astronomy Education Review 10(1) (2011). https://doi.org/10. 3847/aer2011036

I. Ismail, S. Bokhare, S.N. Azizan, N. Azman, Teaching via Mobile phone: A case study on Malaysian teachers' technology acceptance and readiness. The Journal of Educators Online 10(1) (2013). https://doi.org/10.9743/jeo.2013.1.3

James, P. T. (2008, December 11). The 5th Wave Challenges and Opportunities for Mobile-learning in Thailand [PDF]. Bangkok: Fifth International Conference on eLearning for Knowledge-Based Society

Kimura, M. (n.d.). Mobile learning using Mobile phones in Japan. Open Source Mobile Learning Advances in Mobile and Distance Learning,64-83. doi:https://doi.org/10.4018/978-1-60960-613-8.ch005

Y. Liu, F. Hu, H. Li, Understanding learners perspectives on m-learning. Proceedings of the 2009 Euro American Conference on Telematics and Information Systems New Opportunities to Increase Digital Citizenship - EATIS, 09 (2009). https://doi. org/10.1145/1551722.1551728

Lohr, M. (2011). E-Learning Using iPads - An e-learning Scenario Using Mobile Devices and Sensors for Measurements. 2011 IEEE 11th International Conference on Advanced Learning Technologies. doi:https://doi.org/10.1109/icalt.2011.75

Mobile cellular subscriptions (per 100 people) | Data. (n.d.). Retrieved from https://data.worldbank.org/indicator/IT.CEL.SETS. P2?view=map

Mobile Learning Application Development Fostering High Order Thinking Skills on Physics Learning. (2017). Higher Education and Innovation Group in Education (HEA/G) Jan. 8-9, 2017 Bali (Indonesia). Doi:https://doi.org/10.15242/heaig.h0117523

J.L. Mueller, E. Wood, D.D. Pasquale, R. Cruikshank, Examining Mobile Technology in Higher Education: Handheld devices in and out of the classroom. International Journal of Higher Education 1(2) (2012). https://doi.org/10.5430/ijhe.v1n2p43

Olasoji, R., Preston, D., \& Mousavi, A. (2014). Requirement engineering for effective Mobile learning: Modelling Mobile device technologies integration for alignment with strategic policies in learning establishments. Proceedings of the 2014 Federated Conference on Computer Science and Information Systems. doi:https://doi.org/10.15439/2014f98

N.C. Ozuorcun, F. Tabak, Is M-learning versus E-learning or are they supporting each other? Procedia - Social and Behavioral Sciences 46, 299-305 (2012). https://doi.org/10.1016/j.sbspro.2012.05.110

M. Sass, in Handbook of Mobile Teaching and Learning. Service-learning application in an M-learning course (2015), pp. $753-767$. https://doi.org/10.1007/978-3-642-54146-9_86

M. Sharples, The design of personal mobile technologies for lifelong learning. Comput. Educ. 34(3-4), 177-193 (2000). https://doi.org/10.1016/s0360-1315(99)00044-5

N.M. Suki, Students' demand for smartphones. Campus-Wide Information Systems 30(4), 236-248 (2013). https://doi.org/10. 1108/cwis-03-2013-0013

Ten billion downloads and counting: The history of Apple's App Store, and its all-time top apps. (n.d.). Retrieved from https://www.fiercewireless.com/special-report/ten-billion-downloads-and-counting-history-apple-s-app-store-and-itsall-time-top

J. Traxler, Defining, discussing and evaluating Mobile learning: The moving finger writes and having writ. The International Review of Research in Open and Distributed Learning 8(2) (2007). https://doi.org/10.19173/irrodl.v8i2.346

Y. Zhang, in Handbook of Mobile Teaching and Learning. Design of Mobile Teaching and Learning in higher education, an introduction (2015a), pp. 1-6. https://doi.org/10.1007/978-3-642-41981-2_10-1

Y. Zhang, in Handbook of Mobile Teaching and Learning. Development of Mobile application for higher education: An introduction (2015b), pp. 1-4. https://doi.org/10.1007/978-3-642-41981-2_15-1 